\title{
Children with Acute Abdominal Pain: How Many of Them will have a Diagnosis Eventually?
}

\author{
Akut Karın Ağrıı Çocuklar: Hastaların Ne Kadarı Sonunda Bir Tanı Alır?
}

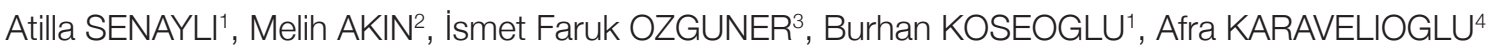

\author{
${ }^{1}$ Keçiören Education and Training Hospital, Department of Pediatric Surgery Ankara, Turkey \\ ${ }^{2}$ Şişli Etfal Education and Training Hospital, Department of Pediatric Surgery Istanbul, Turkey \\ 3Sami Ulus Pediatric Diseases Education and Training Hospital, Ankara, Turkey \\ ${ }^{4}$ Afyonkarahisar Zübeyde Hanım Gynaecology and Pediatric Diseases Hospital, Afyonkarahisar, Turkey
}

\begin{abstract}
Objective: There are many causes of acute abdominal pain in children. This kind of patients, therefore, become a major problem for physicians. In this study, we aimed to investigate how many children with acute abdominal pain have a diagnosis ultimately.

Material and Methods: Data obtained from patient charts containing pre-diagnosis like "acute pain"or "abdominal pain, undefined" was collected retrospectively. These charts data was investigated for age, gender, referring clinic, laboratories and final diagnosis. Complete blood count, serum biochemistry, urine and stool analysis, urine culture, C-reactive protein, erythrocyte sedimentation rate, plain abdominal X-ray, ultrasonography results were documented. Laboratory examinations were classified as normal and abnormal findings. Absence of laboratory studies was also noted to show the physicians' preference.
\end{abstract}

Results: Records of 436 patients with a compianit of abdominal pain were investigated. Of these patients, 354 patients were eligible for our selection criteria and suited for International Coding for Diseases. Gender distribution (189 male, 165 female) and median ages within both genders (males 9 and females 10 years) were similar. Most of the patients did not have a final diagnosis after laboratory investigations. There was no difference between the groups in terms of using laboratory tests except urine culture. Plain abdominal X-ray or ultrasonography was used infrequently. In the end, 83\% of the patients did not have an eventual diagnosis. Both complete blood count and ultrasonography results were found more meaningful in the diagnosed group.

Conclusion: Undiagnosed patients composed the biggest group in our study. Most of the patients with undiagnosed abdominal pain primarily have admitted to our paediatric surgery department. Both the laboratory and radiological tests have been used infrequently among the children having acute abdominal pain in our hospital.

Key Words: Acute, Abdomen, Children, Diagnosis, Pain

\section{ÖZET}

Giriş ve Amaç: Çocuklarda akut karın ağrısının pek çok nedeni vardır. Bu nedenle, bu hasta grubu hekimler için önemli bir sorun teşkil eder. Bu çalışmada, akut karın ağrısıyla başvuran çocukların ne kadarında sonuçta bir tanıya ulaşabildiğimizi araştırmayı amaçladık.

Gereç ve Yöntemler: "Akut ağrı","karın ağıısı, tanımlanmamış" gibi ön tanı içeren dokümanlar geriye dönük olarak toplandı. Bu dokümanlar yaş, cinsiyet, yönlendiren klinikler, laboratuvarlar ve nihai tanı açısından araştırıldı. Kan sayımı, biyokimya, idrar, gaita, düz karın grafisi, ultrasonografi, mikrobiyolojik değerlendirme sonuçları ve diğer laboratuvar verilerine göre konulan tanılar değerlendirildi. Laboratuvar çalışmaları normal ve anormal olarak sınıflandırılı.

Bulgular: Toplam 436 hastanın 354 tanesi Uluslararası Hastalık Kodlamasına ve çalışmaya esas teşkil eden kriterlere uygun olduğu için değerlendirmeye alındı. Erkek ve kız sayıları sırasıyla, 189 ve 165 'di. Erkek ve kız ortanca yaşı sırasıyla 9 ve 10 yıldı. Hastaların büyük bir kısmı laboratuvar çalışmaları sonunda tanı almadı. İdrar kültürü dışında laboratuvar testleri kullanımı açısından gruplar arasında fark yoktu. Düz karın grafisi veya ultrasonografi seyrek olarak kullanılmıştır. Sonuç olarak hastaların \%83'ün de bir tanıya ulaşılamadı. Tam kan sayımı ve ultrasonografinin sonuçlarının tanı almış grupta daha anlamlı olduğu bulundu.

Sonuç: Çalışmamızda tanı almamış hastalar en büyük grubu oluşturmaktadır. Teşhis edilmemiş hastaların çoğu doğrudan çocuk cerrahisi kliniğimizi ziyaret etmiştir. Hastanemizde akut karın ağrılı çocuklarda hem laboratuvar hem de radyolojik testler oldukça az oranda kullanılmaktadır.

Anahtar Sözcükler: Akut, Karın, Çocuklar, Tanı, Ağıı 


\section{INTRODUCTION}

Pain is an important fact affecting the public health at the pediatric age group (1). Pain may occur in a wide-spectrum ranging between self-limited conditions and an emergency (2). Most of the pains are not based on organic reasons, and medical evidences are rarely found (3). In addition, few children are successful for describing their symptoms, and clinical signs (4). Although practitioners use multiple laboratory investigations, acute abdominal pain diagnosis may be challenging $(5,6)$.

Some authors are in the opinion that laboratory studies must be special for patients (2). In contrast to this, there may be standard type of evaluation steps, and laboratory investigations may start with blood cell count and urinalysis (2). The authors wish to facilitate the diagnosis of a disease most likely to opt for a single target may need to be evaluated (7). Active patient observation is a useful instrument to find a diagnosis. (6). Radiological and laboratory investigations may be designed after the evaluation of demographic and clinical features (7).

In our study, we aimed to investigate the clues of systematic evaluation of acute abdominal pain in children. Literature has little data on these patients. We suppose that this study may provide additional information for the clinical management of children with acute abdominal pain.

\section{MATERIAL and METHODS}

A retrospective review of patient charts between 2005 and 2011 was conducted in our pediatric surgery department. Patient charts including "acute pain", "abdominal pain" and "undefined" pre-diagnostic definitions were evaluated. Demographic data of the patients, type of admission, referring department, laboratory findings and final diagnosis of the patients were recorded. Final diagnosis was assessed after the evaluation of the laboratory results and patients with a final diagnosis were included in un-diagnosed group.

Exclusion criteria of the patients were; Patients were excluded from the study if had:

a- Having a previous history of abdominal surgery

b- Obvious findings of a specific disease during the first visit

c- Having an additional pre-diagnosis of a surgical disease

d- Having a chronic disease that may cause acute on set of abdominal pain

e- More than one visit for acute abdominal pain

f- Suffering from acute pain after a trauma history

g- Patients visiting or have referred to paediatric surgery department a day after the first visit to emergency or other departments ( being not suitable for acute abdominal pain process).

h- Having an evident location of pain in an abdominal quadrant
Laboratory evaluations included complete blood count, serum biochemistry, urine culture, urine and stool analysis.

Complete blood count: This laboratory test was particularly used for detecting the inflammatory response of the body. So, white blood cell (WBC) count and neutrophil percentage (NEU $\%)$ were taken into account. WBC value greater than $10 \times 10^{3} /$ $\mathrm{mL}$ and NEU rate greater than $75 \%$ were defined as abnormal.

Serum biochemistry: The evaluated serum biochemistry values with normal ranges were glucose (80-120 mg/dl), aspartate transaminase (AST) (0-40 U/L), alanine transaminase (ALT) (0-40 U/L), sodium (Na) (138- $145 \mathrm{mmol} / \mathrm{L})$, potassium (K) (2-4 $\mathrm{mmol} / \mathrm{L})$. Values other than the normal ranges were accepted as abnormal.

Urine analysis: To determine the urinary inflammation particularly leukocyte counts were evaluated. Microscopic count of $\geq 5$ leukocyte in an area or $\geq 75$ leukocyte per millilitre with electronic counter was accepted as abnormal.

Urine culture: Any growth $\geq 10^{5} \mathrm{cfu} / \mathrm{ml}$ was accepted as urinary infection.

Stool analysis: Definitions for parasitosis, candidiasis and white cells greater than 10 per area in microscopy was accepted as abnormal.

Other studies: $\mathrm{C}$ - reactive protein $(\mathrm{CRP})$ and erythrocyte sedimentation rate were used to determine systemic inflammatory response. CRP values greater than 0.8 and sedimentation rates greater than $20 \mathrm{~mm} /$ hour were accepted as abnormal.

Imaging studies: Plain abdominal X-ray and ultrasonography (US) were investigated. Paediatric surgeons evaluated plain abdominal graphs and findings of obstructive signs were defined as abnormal.

Statistics: SPSS 15.0 statistic package software (SPSS Inc, Chicago III) was used for statistics analysis. For analysis of categorical variables Fisher's exact test was used. For all the analysis a $p$ value lower than 0.05 was accepted statistically significant.

\section{RESULTS}

Records of 436 patients complaining with abdominal pain were found. However, 82 patients were excluded. Three hundred and fifty four patients were eligible for our selection criteria and suited for International Coding for Diseases. Thirteen different diseases were diagnosed during the evaluations (Table I).

There were 293 patients in undiagnosed group whereas 61 patients could be diagnosed. The most commonly diagnosed diseases were respiratory tract infection, appendicitis, urinary tract infection and constipation ( $n=61$ ). Of the patients, 85\% were admitted to the paediatric surgery department, $9 \%$ emergency room, 5\% paediatrics and 1\% other departments, 
initially. There was no statistically significant difference between the groups, in terms of, complete blood count, serum biochemical tests, urinalysis, stool analysis, X-ray and the US usage (Table II). Urine culture was used more frequently in the diagnosed group. More positive results were obtained in diagnosed group when compared with the undiagnosed group in terms of complete blood count and US (Table III). Plain abdominal X-rays were found normal in both groups.

Only one patient had positive urinary culture and diagnosed as urinary tract infection. All of the CRP $(n=14)$ values and erythrocyte sedimentation rates $(n=6)$ were abnormal and patients with abnormal erythrocyte sedimentation rates were in the undiagnosed group.

Table I: Age and gender distribution of the patients.

\begin{tabular}{|l|c|c|c|}
\hline Diagnosis & No. Patients & Age (m/f) & Gender (m/f) \\
\hline Appendicitis & 10 & $(16 / 13)$ & $(7 / 3)$ \\
\hline Urinary Tract Infection & 7 & $(15 / 15)$ & $(4 / 3)$ \\
\hline Gastroesophageal Reflux & 3 & $(12 / 0)$ & $(4 / 0)$ \\
\hline Inguinal Hernia & 4 & $(10 / 0)$ & $(0 / 5)$ \\
\hline Ovarian Cyst & 5 & $(0 / 16)$ & $(1 / 0)$ \\
\hline Perihepatic Abscess & 1 & $(14 / 0)$ & $(1 / 0)$ \\
\hline Parasitosis & 1 & $(12 / 0)$ & $(0 / 1)$ \\
\hline Conversion & 1 & $(0 / 17)$ & $(3 / 4)$ \\
\hline Constipation & 7 & $(11 / 11)$ & $(3 / 3)$ \\
\hline Gastroenteritis & 6 & $(15 / 12)$ & $(0 / 1)$ \\
\hline Vaginal Inflammation & 1 & $(0 / 18)$ & $(7 / 7)$ \\
\hline Respiratory Tract Infection & 14 & $(14 / 11)$ & $(0 / 1)$ \\
\hline Dysmenorrhea & 1 & $(0 / 18)$ & $(156 / 137)$ \\
\hline Undiagnosed & 293 & $(12 / 13)$ & $(189 / 165)$ \\
\hline Total & 354 & $(9 / 10)$ & \\
\hline
\end{tabular}

Table II: The usage of diagnostic tests between groups.

\begin{tabular}{l|c|c|c}
\hline & Diagnosed $\mathbf{n = 6 1 ( 1 7 \% )}$ & Undiagnosed $\mathbf{n = 2 9 3}(\mathbf{8 3} \%)$ & $\mathbf{p}$ value* \\
\hline Complete blood count & $14(23 \%)$ & $63(21.5 \%)$ & 0.865 \\
\hline Serum biochemistry & $7(11.5 \%)$ & $36(12.3 \%)$ & 1.000 \\
\hline Urine analysis & $10(16.4 \%)$ & $64(21.8 \%)$ & 0.391 \\
\hline Stool analysis & $4(6.6 \%)$ & $16(5.5 \%)$ & 0.760 \\
\hline Plain abdominal X-Ray & $5(8.2 \%)$ & $21(7.2 \%)$ & 0.788 \\
\hline Urine culture & $6(9.8 \%)$ & $4(1.4 \%)$ & 0.02 \\
\hline C - reactive protein & $4(6.6 \%)$ & $10(3.4 \%)$ & 0.274 \\
\hline Ultrasonography & $12(19.7 \%)$ & $52(17.7 \%)$ & 0.716 \\
\hline
\end{tabular}

*Fisher's exact test.

Table III: The rate of positive results in diagnostic tests.

\begin{tabular}{l|c|c|c}
\hline & Diagnosed $\mathbf{n = 6 1}(\mathbf{1 7 \% )}$ & Undiagnosed $\mathbf{n = 2 9 3}$ (83\%) & $\mathbf{p}$ value* \\
\hline Complete blood count & $9 / 14(64 \%)$ & $11 / 63(17.5 \%)$ & 0.001 \\
\hline Serum biochemistry & $0 / 7(0 \%)$ & $2 / 36(5.6 \%)$ & 1.000 \\
\hline Urine analysis & $1 / 10(10 \%)$ & $0 / 64(0 \%)$ & 0.135 \\
Stool analysis & $0 / 4(0 \%)$ & $1 / 16(6.3 \%)$ & 1.000 \\
\hline Ultrasonography & $8 / 12(66.7 \%)$ & $1 / 52(1.9 \%)$ & $<0.001$ \\
\hline
\end{tabular}

*Fisher's exact test. 


\section{DISCUSSION}

To date, authors have conducted a few investigations concerning the acute abdominal pain in children (8). Underestimation of this problem may have many reasons. However, the most important reasons are being a common complaint and surgery is not usually required after the evaluations $(4,6)$. According to us, evaluation of the abdominal pain is a time consuming task thus the institutes don't want to spend time on these problems. On the other hand, surgical diseases, if present, may be serious and child's stress may interrupt the operator to diagnose the important situation (6). As a collaboration of multiple factors including all the aforementioned parameters, someone can say that a patient with non-specific abdominal pain must be observed until the main reason of the complaint settles (6). Also, taking good history, and performing good physical examination may be determinative for authors (6). Terms of acute abdominal pain for more guides do not answer the question about the know-how.

The literature is lack of such studies and there are pieces of data to work on it. It is reported that patients complaining of acute abdominal pain are commonly encountered in pediatric emergency departments (4). In our study, we revealed that most of the patients were primarily had evaluated in the pediatric surgery department. Of the 354 patients, 301 had admitted to pediatric surgery department, initially. According to us, this data indicate that in our region parents usually prefer surgeons for physical examinations when abdominal pain is present. So, this may predict that parents in our region are usually afraid of surgical diseases. Parents' confidence in the surgeon to these conditions may be another reason.

In our series, medial ages of males and females were 9 and 10 years old, respectively. Some diseases were gender specific, do not cover the other gender. So, this situation may alter the medial age of the other gender. After exclusion of these factors for male and female patients, medial ages were 13 and 10 respectively. As a result, most of the patients were preadolescents. In the literature, there is no data evaluating the effect of age so we're not sure about the meaning of this finding. Most of the patients with undefined acute abdominal pain in our study were pre-adolescents, thus we speculate that being preadolescent may be a predicting factor for undiagnosed acute abdominal pain.

Complete blood count and serum biochemistry evaluations are supposed to be diagnostic factors for the different diseases. However, a few of these tests have played a role in the diagnosis of diseases in our study. Of the 77 performed complete blood count tests, only $10(10 / 354,2.8 \%)$ tests took a part in the diagnosis of a disease. In our series, complete blood count was commonly found to be effective for the diagnosis of appendicitis.

Among the 43 serum biochemistry tests none of the parameters were effective for the diagnosis of diseases. Unfortunately serum biochemistry evaluations for the acute abdominal pain were absent in literature. So, in theory, it can be possible that some important clues of the diseases may be missing.

Urine and stool analysis were useless for undiagnosed abdominal pain. In our series, we found only one abnormal result in the undiagnosed group. In a study concerning the evaluation of acute abdominal pain, dipsticks usage was advised for a quick exclusion of urinary tract infection (9).

Plain abdominal radiography and US were the main imaging tools. However, there was no abnormal plain abdominal radiography finding and only 8 US evaluations revealed a significant result for the diagnosis. Again appendicitis was the most commonly diagnosed disease evaluated by US. In the literature, plain abdominal radiography has usually been used for evaluating intestinal obstruction or perforation (2). US and computed tomography are commonly used for urgent acute abdominal pain (2). In some institutions, US are supposed to be helpful in diagnosing appendicitis. However, US can rarely determine appendix (10). In our series, among the 64 patients only 5 patients were diagnosed as appendicitis with US.

Urinary culture may guide the clinicians for delayed diagnosis of acute abdominal pains. However in our study, we encountered a few urinary cultures and only one culture revealed a urinary tract infection. CRP value and erythrocyte sedimentation rate may be helpful but have found only 4 CRP evaluations meaningful for diagnosis and 3 of these diagnoses were appendicitis.

In this study, data obtained by retrospective patient chart scanning and very rare usage of both the laboratory and radiologic tests, were the limitations. Both complete blood count and US results was found to be more meaningful in the diagnosed group.

In conclusion, there is no know-how, decision-making arrangement for acute and undiagnosed abdominal pains in children. Nowadays, literature is restricted and a few data is present. Clinical, cohort or archive evaluations must be investigated. Collection of these data will help to define the undiagnosed acute abdominal pains.

We suppose that with careful evaluation and planning of the necessary laboratory and imaging studies, more children with acute abdominal pain can be diagnosed.

\section{REFERENCES}

1. Roth-Isigkeit A, Thyen $U$, Stöven $H$, Schwarzenberger J, Schmucker P. Pain among children and adolescents: Restrictions in daily living and triggering factors. Pediatrics 2005;115:e152-e62.

2. Leung AKC, Sigalet DL. Acute abdominal pain in children. AFP 2003;67: 2321-6.

3. Walker LS, Williams SE, Smith CA, Garber J, Van Slyke DA, Lipani $\mathrm{T}$, et al. Validation of a symptom provocation test for laboratory studies of abdominal pain and discomfort in children and adolescents. J Pediatr Psychol 2006;31:703-13. 
4. Carrico CW, Fenton LZ, Taylor GA, DiFiore JW, Soprano JV. Impact of sonography on the diagnosis and treatment of acute lower abdominal pain in children and young Adults. AJR Am J Roentgenol 1999;172:513-6.

5. Davenport M. Acute abdominal pain in children. BMJ 1996;312; 498-501.

6. Jones PF. Active observation in management of acute abdominal pain in childhood. Br Med J 1976;2:551-3.

7. Anatol TI, Holder Y. A scoring system for use in the diagnosis of acute abdominal pain in childhood. West Indian Med J 1995;44: $67-9$
8. Yücel A. Çocukluk çağı ve ağrı epidemiyolojisi. In: Yücel A. Özyalçın NS, (eds). Çocukluk çağında ağrı. $1^{\text {st }}$ ed, Istanbul: Nobel Tip Kitapevleri, 2002;1.

9. Woodward MN, Griffiths DM. Use of dipsticks for routine analysis of urine from children with acute abdominal pain. BMJ 1993;306:1512.

10. Patriquin HB, Garcier JM, Lafortune M, Yazbeck S, Russo P, Jequier $S$, et al. Appendicitis in children and young adults: Doppler sonographic-pathologic correlation. AJR Am Roentgenol 1996;166:629-33. 